\title{
ACCOMMODATING THE SECURITIES LAWS TO EMPLOYEE BENEFIT PLANS
}

\author{
SIMON M. LORNE*
}

The recent decision of the Supreme Court in International Brotherhood of Teamsters $v$. Daniel ${ }^{1}$ is a pyrrhic victory for those who argue for a rational accommodation of the securities laws to employee benefit plans. While the threat of hability under Rule $10 b-5^{2}$ of the Securities and Exchange Commission (SEC) may have put fear in the hearts of inany, ${ }^{3}$ that threat was only a minor aspect of the irrationality of trying to govern employee compensation arrangements by laws designed for vastly different purposes. Although the relatively narrow Daniel opinion may have removed the immediate fear, the decision has only increased the likelihood of continuing an unduly complicated set of rules for coordinating many legitimate employer-employee desires within a securities law framework.

Recent developinents in the regulation of Employer Stock Ownership Plans (ESOPs) ${ }^{4}$ exemplify the irrational results that can occur when the securities laws are applied hterally to employee benefit plans. Congress initially desired to encourage the use of ESOPs. Accordingly, Congress provided that a corporation that establishes ESOPs may deduct casli payments made to the plans or the value of contributions in its own securities made to the plans and that employee-beneficiaries of such a plan need not recognize the amount of the contribution as income until actual distributions from the related trust are made to them. ${ }^{5}$ For many reasons, these plans gained mucl favor among employers. Securities lawyers, however, began to ask the SEC wliether employees who received the employer shares in distributions when they retired were entitled to sell them, or whether the 1933 Act imposed restrictions on such subsequent sales. The answer to this question was unclear since the sale of shares to ESOPs from the corporation typically

* A.B. 1967, Occidental College; J.D. 1970, University of Michigan Law School. Member of the California Bar. Formerly Acting Director (1977-78), University of Pennsylvania Law School Center for Study of Financial Institutions.

1. 99 S. Ct. 790 (1979).

2. 17 C.F.R. $\$ 240.10 \mathrm{~b}-5$ (1978).

3. See, e.g., 124 CoNG. REC. S6581 (daily ed. May 1, 1978) (remarks of Sen. Williams).

4. See Part I C infra.

5. I.R.C. $\$ 403$. 
had not been registered under the Securities Act of $1933 .^{6}$

The SEC, interpreting the 1933 Act and Rule $144^{7}$ literally, initially determined that such shares were "restricted" in the hands of employee recipients. The SEC decided that employees could sell the shares only in certain circumstances, for example, after holding them for a minimum of two years. The Internal Revenue Service, however, in an effort to effectuate Congress' mandate to aid employees, promulgated regulations requiring certain employers to give employees a "put" option. An employee who received such an option could sell the stock that had been distributed to him back to the corporation for a specified length of tinie. ${ }^{8}$

That is not a rational resolution, for under the terms of Rule 144 the very existence of the "put" delayed until its expiration the two-year holding period that must precede a sale. ${ }^{9}$ Thus, the outcoine of this internecime conflict was that the employee-beneficiaries had a right to sell the shares back to the corporation but would have to wait an additional period before making any public sales.

While that particular problem appears now to have been satisfactorily resolved, at least in the most significant instances, ${ }^{10}$ it does illustrate the types of problems that will be encountered if the securities laws are literally applied to employee benefit plans. Quite simply, the securities laws by and large are designed for purposes quite foreign to such plans. While inuclı has been written about accommodating employee benefit plans to the securities laws, ${ }^{11}$ it is more useful, or at least inore hopeful, to devote some time to discussing ways in which the securities laws can be accommodated to the realities of employee plans. There is no logical reason why the securities laws should dictate the design and administration of employee plans. If sucl plans, which are otherwise acceptable to society, conflict with the securities laws, then the securities laws, in inany cases, should adapt to these plans.

That is not, lowever, to suggest that there is no role for the securities laws to play in the area of employee benefit plans. The securities

6. 15 U.S.C. $\$ \S 77 a-77 a a(1976)$. See text accompanying notes 37-41 infra.

7. 17 C.F.R. $\S 230.144$ (1978). See text accompanying notes 69-70 infra.

8. Treas. Reg. § 54.4975-7(b)(10) (1977); Ludwig, Analysis of Final ESOP Regulations, 1978

U.S. Cal. L. Center TaX Inst. 381, 425-28.

9. Rule 144(d)(3), 17 C.F.R. § 230.144(d)(3) (1978).

10. See, e.g., Securities Act Release No. 5750 (Oct. 8, 1976), [1976-1977 Transfer Binder] Fed. SeC. L. Rep. (CCH) I 80,766.

11. See, e.g., Bermant, The Securities Law Aspects of Executive Compensation, 1978 U.S. CAL. L. Center TAX Inst. 345; Holland \& Yerkes, Employee Benefit Plans and Federal and California Securities Laws, 33 Bus. LAw. 1727 (1978); Hyde, Employee Stock Plans and the Securities Act of 1933, 16 W. RES. L. REv. 75 (1964); Mundheim \& Henderson, Applicability of the Federal Securities Laws to Pension and Profit-Sharing Plans, 29 L. \& CoNTEMP. PROB. 795 (1964). 
laws are designed to protect investors (primarily through the 1933 $\mathrm{Act}^{12}$ ) and to protect securities markets (primarily through the Securities Exchange Act of $1934^{13}$ ). Einployee benefit plans affect employeremployee relationships and, particularly to the extent that such plans involve investinent in employer securities, may significantly affect the market for those securities. The employer-employee relationship may be comparable in meaningful ways to the issuer-investor relationship: both the employee and the investor commit assets to the corporation, the position of both is improved by the corporation's success and both suffer harm if the corporation falls on hard times. Nonetheless, the two relationships are obviously and fundamentally different. If additional regulation in the employment environment is desirable, it is the employenent relationship that should be regulated, and regulation should be administered by people sensitive to that relationship. However, when such plans do have an impact on the securities markets generally, there is an important function to be served by securities-oriented regulation. Thus, the thesis of this Article is that the securities laws should be amended-or interpreted ${ }^{14}$-m such a manner that they will not unduly interfere with the employment relationship.

\section{Types of Employee Benefit Plans}

A variety of plans have been developed to provide employees with retireinent or interim benefits. The following listing, while not complete, indicates the broad spectrum of plans and provides a background for discussion of the various areas of potential conflict between the securities laws and employee benefit plans.

\section{A. Pension Plans.}

These plans are generally designed to provide employees with some form of predetermined benefits upon retirement. Some varieties establish a defined contribution so that benefits depend upon contributions made to the participant's individual account prior to retirement as well as on the investunent experience of the account. The different plans are thus characterized as "defined benefit" plans or "defined contribu-

12. 15 U.S.C. $\$ \S 77 a-77 a a(1976)$.

13. Id. §§ 78a-78kk (1976).

14. While this Article may seem generally to urge a congressional reevaluation of the securities laws, it does not do so because the author is attracted to the legislative process. Many of the changes suggested in this Article could be accomplished by the SEC administratively. The SEC's amicus brief on the losing side of the 8-0 decision in Daniel, however, is too indicative of that agency's general position to allow much hope that the agency will accept a movement away from regulation in this field. 
tion" plans. ${ }^{15}$ They may be contributory-financed by both employer and employee contributions-or non-contributory-financed solely by employer contributions. ${ }^{16}$ They may be premised upon voluntary or compulsory participation by employees. Such plans may be union- or co-administered (a trust fund is establislied for union members to which different employers contribute in accordance with imdividual union contracts), independently administered (administration of the plan is contractually assigned to one or more independent firms) or, in some limited circumstances, company administered (the employer retains administrative powers over the pension fund, typically through a committee of meinbers of the board of directors).

The administration of such pension plans may involve both record-keeping functions-determining amounts attributable to individual participants, making required reports, dispensing checks-as well as investment decisions with respect to pension plan funds. Investment of sucli funds in einployer securities is subject to a number of different limitations, depending on the type of plan and the type of security.

\section{B. Profit Sharing Plans.}

These plans, substantially more prevalent among non-union companies and einployees, do not establish a specific contribution or benefit level. Rather, contributions are made as a specified percentage or within a specified range of profits, and benefits depend on the participant's sliare of contributions actually made prior to retireinent. Such plans may be company administered or independently administered, and various limitations preclude any substantial part of the assets of most plans froin being imvested in employer securities.

\section{Employer Stock Ownership Plans (ESOPS).}

These plans differ markedly from the typical pension and profit sharing plans outlined above. In ESOPs the plan's assets are invested for the most part, if not entirely, in employer securities, purchased either in the open market or directly from the einployer. In some cases, the employer makes its contribution to the plan in the form of einployer securities ratler than cash. Upon retirement, the participant re-

15. See R. Pozen, Financial Institutions: Cases, Materials and Problems on INvestment MANAGEMENT 598 (1978). See also SEC Amicus Brief at 12-13, International Bhd. of Teamsters v. Daniel, 99 S. Ct. 790 (1979).

16. The plan at issue in Daniel, and the only type of plan to which that decision relates, was a compulsory, non-contributory, defined benefit plan. $99 \mathrm{~S}$. Ct. at 792. In the aftermath of Daniel, at least one court has extended that holding to contributory plans. See Tanuggi v. Groher, Inc., [1978-1979 Transfer Binder] Fed. SEC. L. REP. (CCH) \ 96,880 (S.D.N.Y. May 14, 1979). 
ceives employer securities according to a predetermined formula or, alternatively, the cash value of such securities. Because these plans utilize employer securities to such a great degree, they raise many inore complex questions with respect to the interpretation and application of various securities laws than do ordinary pension or profit sharing plans.

\section{Stock Option Plans.}

These plans are not actually retirement plans, but rather are simply a forn of additional compensation available at the discretion of the board of directors to individual employees, usually in the managerial ranks. Under these plans the einployee has the option of acquiring employer securities over a period of years at a price established on the date the option is granted.

\section{E. Stock Appreciation Right (SAR) Plans.}

SAR plans were developed im recent years as a refineinent of stock option plans to provide similar benefits with a reduced imvestment. Participants are granted what is in effect a stock option, but are given the cloice during the option period of (1) purchasing the securities at the exercise price; (2) surrendering the option for an amount of cash equal to the difference between the exercise price and the fair market value of the security on the date of surrender, times the number of shares subject to the option; or (3) surrendering the option for the number of shares of the security that the amount of casli referred to in the second option would be able to buy in the narket on the date of surrender.

\section{Securities Law Provisions That have an Impact on EMPLOYEe Plans}

The different employee benefit plans outlined above may be affected by many provisions of the securities laws. From the viewpoint of the employer and the employee, the pertinent provisions are found primarily in the 1933 Act, the 1934 Act and the rules promulgated under those acts. Although the Investment Coinpany Act of $1940,{ }^{17}$ the Investment Advisers Act of $1940^{18}$ and the provisions of the 1934 Act

17. 15 U.S.C. $\$ 80 \mathrm{a}$ (1976). This act regulates companies whose primary function is the investment of funds in securities; it also places controls on the relationships between such companies and those who manage thein.

18. Id. $\S 80 \mathrm{~b}$. This act regulates persons whose business is advising others with respect to securities and investments. 
relating to registered broker dealers ${ }^{19}$ are also important (particularly to those who invest, provide investment advice or execute trades for plan assets), they are beyond the scope of this Article and are not considered below. Because the thesis of this Article is that the purposes of the securities laws are generally sufficiently distinct from the societal interest in regulating employee plans as to require major amendments to the securities laws, the following is only a brief examination of the applicable laws.

\section{A. Security.}

Unless an interest in an employee benefit plan involves a security, no provisions of the securities laws have any bearing on the plan. "Security" is defined in section 2(1) of the 1933 Act as "any . . . certificate of interest or participation in any profit-sharing agreement, ... . [or] investment contract, . . . any interest or instrument commonly known as a 'security,' or any certificate of interest or participation im . . . any of the foregoing."20 The use of the term in the 1934 Act is sufficiently similar that there are few, if any, inatters that would be a security under one law and not under the other. ${ }^{21}$ The term was given a broad interpretation in the four decades following the 1933 Act to include virtually any transaction in which money was given to another with an expectation of return. ${ }^{22}$ In the benchmark case of SEC v. W.J. Howey Co. ${ }^{23}$ the critical factors were whether "a person invests his inoney in a common enterprise and is led to expect profits solely from the efforts of the promoter or a third party." 24 Under that theory, such unlikely interests as scotch whisky warehouse receipts ${ }^{25}$ and gold com portfolios ${ }^{26}$ have

19. Certain portions of the 1934 Act, primarily $\$ \S 7-11,15,17$ and 18 (15 U.S.C. $\$ \$ 78 \mathrm{~g}-78 \mathrm{k}$, 78o, 78q and 78r (1976)), regulate various activities of those who engage in the business of purchasing and selling securities to or for others. Obviously, these provisions can be important with regard to retirement plans, which by their nature control substantial fimds for investment.

20. 15 U.S.C. \& 77b(1) (1976).

21. The definition is found at $\S 3(\mathrm{a})(10)$ of the 1934 Act, 15 U.S.C. $\$ 78 \mathrm{c}(\mathrm{a})(10)(1976)$. See International Bhd. of Teamsters v. Daniel, 99 S. Ct. at 795 n.7; United Hous. Foundation, Inc. v. Forman, 421 U.S. 837, 847 n.12 (1975); Tcherepnin v. Knight, 389 U.S. 332, 335-36, 342 (1967).

22. See, e.g., Tcherepnin v. Knight, 389 U.S. 332 (1967); SEC v. Gleun W. Turner Enterprises, Inc., 474 F.2d 476 (9th Cir.), cert. denied, 414 U.S. 821 (1973); Blackwell v. Bentsen, 203 F.2d 690 (5th Cir. 1953), cert. dismissed, 347 U.S. 925 (1954); Penfield Co. v. SEC, 143 F.2d 746 (9th Cir.), cert. denied, 323 U.S. 768 (1944); SEC v. Universal Serv. Ass'n, 106 F.2d 232 (7th Cir. 1939), cert. denied, 308 U.S. 622 (1940); SEC v. Crude Oil Corp. of America, 93 F.2d 844 (7th Cir. 1937); SEC v. Bourbon Sales Corp., 47 F. Supp. 70 (W.D. Ky. 1942); Silver Hills Country Club v. Sobieski, 55 Cal. 2d 811 , 361 P.2d 906, 13 Cal. Rptr. 186 (1961); I L. Loss, Securities RegulaTION $455-512$ (2d ed. 1961).

23. 328 U.S. 293 (1946).

24. Id. at 299.

25. Glen-Arden Commodities, Inc. v. Costantino, 493 F.2d 1027 (2d Cir. 1974).

26. SEC v. Brigadoon Scotch Distrib., Ltd., 388 F. Supp. 1288 (S.D.N.Y. 1975). 
been held to be "securities," at least under some circumstances.

In 1975, however, in United Housing Foundation, Inc. v. Forman, ${ }^{27}$ the Supreme Court imdicated a more restrictive approach, holding that documents called shares of stock were not securities when acquired as a minor part of a purchase of an apartunent where the purchasers were in fact making a housing decision rather than an investment decision.

As applied to interests im employee benefit plans, similar questions obviously arise. The Court's holding in Daniel that the interests in the union-administered, non-contributory, compulsory pension plan there at issue did not constitute a "security," for reasons similar to those enunciated in Forman, is dispositive only as to plans of that type. Generally, the question is whether the interest that is "acquired" has the elements of a traditional security investment. ${ }^{28}$

\section{B. Sale.}

Once a security is found to exist, the second element of the analysis is whether the security has been "sold." Unless the security has been "sold," no significant securities law rights attach to the transaction. A "sale" is defined in the 1933 Act as "any disposition . . . for value."29 The 1934 Act is somewhat broader, requiring simply "any contract to sell or otherwise dispose," 30 but authorities have generally viewed the definitions as having the same meaning. ${ }^{31}$ The view of the SEC for several years, at least with respect to the question whether the grant of interests in benefit plans rcquired registration, was that contributory plans involved a sale but that non-contributory plans did not. ${ }^{32}$ Such a view rested to some extent on a legal fiction, since monetary payments pursuant to an orgamized plan between an employer and einployees certainly lack most characteristics of a gift. However, this view did represent a reasonable attempt by the SEC to keep the securities laws from

27. 421 U.S. 837 (1975).

28. Daniel is intriguing in its rather strict view that a security must have both an "investment of money" and an "expectation of profits from a common enterprise." $99 \mathrm{~S}$. Ct. at 796-97. The Court's discussion of the latter question would appear to suggest that a classical "Ponzi scheine," in which the return to former investors is provided solely from funds "invested" by new investors, does not involve a security - a rather renarkable conclusion.

29. 15 U.S.C. $\& 77(b)(3)(1976)$.

30. Id. $\& 78 \mathrm{c}(\mathrm{a})(14)$.

31. See, e.g., Lawrence v. SEC, 398 F.2d 276, 280 (1st Cir. 1968); 3 H. BloomenthAL, SECURITIES AND FEDERAL CORPORATE LAW 19 (Spec. Supp. 1977). But see Daniel v. International Bhd. of Teamsters, $99 \mathrm{~S}$. Ct. at $795 \mathrm{n} .8$ (expressly leaving the question open).

32. Opinion of SEC Assistant General Counsel, [1941-1944 Transfer Binder] FED. SEC. L. REP. (CCH) ๆ 75, 195 (1941); Letter of Assistant Director, SEC Division of Corporation Finance, 1 FED. SEC. L. REP. (CCH) I 2105.51 (1953); Letter of Chief Counsel, SEC Division of Corporation Finance, 1 FED. SEC. L. REP. (CCH) I 2105.52 (1962); I L. Loss, supra note 22, at 524 n.211. 
unduly interfering with employment relationships, at least where a reasonable excuse for non-intervention existed and where the employee was not making a traditional imvestment decision.

Under the views recently espoused by the SEC, it is argued that the definitions of "security" and "sale" are flexible, so that the terms may have one meaning for the registration provisions of the 1933 Act, for example, and a different uneaning for the antifraud provisions of the same Act. ${ }^{33}$ Such a view, although not entirely unreasonable, seems at odds with accepted notions of legislative intent.

\section{Registration and Exemptions.}

If a "security" is being "sold" when an employee receives an interest in an employee beneflt plan, the first consequence is that the transaction inust be registered under the 1933 Act, unless an exemption is available. ${ }^{34}$ Depending on the nature of the plan and of the employer, that process can be cumbersome and expensive. It may also give rise to substantial potential hability on the part of officers and directors and may require disclosures that could be harmful both to the corporation and, indirectly, to its employees.

There are two exemptions from registration available to most plans, if the plans are structured properly, in addition to the early "no sale" position developed by the SEC. ${ }^{35}$

1. Section 3(a)(2). For most employee plans section 3(a)(2) of the 1933 Act, ${ }^{36}$ added as an amendment to the Act in 1970, ${ }^{37}$ appears to provide an exemption from registration. That section provides that

[e]xcept as . . . expressly provided, the provisions of this subchapter shall not apply to ... any interest or participation in a single or collective trust fund maintained by a bank or in a separate account Inaintained by an insurance coinpany which interest or participation is issued in connection with (A) a stock bonus, pension, or profitsharing plan which ineets the requirements for qualification under section 401 of [the Internal Revenue Code of 1954] . . . or (B) an annuity plan which ineets the requirements for the deduction of the einployer's contribution under section 404(a)(2) of . . . [such Code], other than any plan . . . (i) the contributions under which are held in a single trust fund inaintained by a bank or in a separate account inaintained by an insurance coinpany for a single einployer and under which an aunount in excess of the employer's contribution is

33. See, e.g., SEC Daniel Brief, supra note 15, at 70-77. The Court left this approach unresolved, while suggesting it had doubts as to the SEC's view. 99 S. Ct. at $801 \mathrm{n} .22$.

34. 15 U.S.C. $\$ 77$ e (1976).

35. See text accompanying notes 7-9 supra.

36. 15 U.S.C. $\$ 77 \mathrm{c}(\mathrm{a})(2)$ (1976).

37. Pub. L. No. 91-567, 84 Stat. 1498 (1970). 
allocated to the purchase of securities . . . issued by the employer or by any company directly or indirectly controlling, controlled by or under common control with the employer or (ii) which covers employees some or all of whom are employees within the meaning of section $401(\mathrm{c})(1)$ of . . . [such Code]. ${ }^{38}$

The precise meaning of section $3(\mathrm{a})(2)$ is far from clear. While most employee benefit plans other than stock option plans are of the type covered by the quoted language, it is not clear what "securities" are covered by the exemption, ${ }^{39}$ how important the maintenance of funds in a bank or an insurance company as opposed to other investment vehicles is, and what precisely is meant by a "separate account" or a "single" rather than a "collective" trust fund. 40 Although the provision was adopted to avoid requiring banks or imsurance companies to register, ${ }^{41}$ its necessity is im doubt and its complexity seems clearly without justification. At present, the general view is probably that section 3(a)(2) applies to most einployee benefit plan issuances of the pension, profit sharing or ESOP type.

2. Section 4(2) and Rule 146. Section 4(2) of the 1933 Act exempts froin the registration provisions of that Act transactions "by an issuer not involving any pubhic offering." by the SEC to provide greater certainty regarding whether a pubhic offering is or is not involved: a sale is considered not to imvolve a public offering if made to thirty-five or fewer persons and if all purchasers and offerees are either sophisticated or can bear the economic risk of the investment and have an appropriate "offeree representative."43 While section 4(2) and Rule 146 are useful only with respect to pension and profit sharing plans for the smallest of compames, they are of substantially greater importance im the case of stock option plans or SAR plans that in the medium-sized company may mclude a group of persons smaller in number than thirty-five.

Section 3(a)(2) and section 4(2) are thus sufficient to exempt inany

38. 15 U.S.C. \& 77c(a)(2) (1976).

39. See, e.g., the discussion in SEC Daniel Brief, supra note 15, at 59-61, for the divergent views of the SEC and the International Brotherhood of Teamsters as to whether §3(a)(2) exempts the interests in plans granted to einployees or the interest in bank trust accounts sold by banks to pension plans. While the SEC's views are more persuasive, such fundamental doubt as to the essential meaning and intent of the statute is remarkable. See also $99 \mathrm{~S}$. Ct. at 799.

40. See, e.g., Stafford, Employee Benefit Plans, 11 REv. SEC. REG. 871, 872 (1978). In Daniel the Court properly noted that the legislative history of the 1970 amendments indicates that this language was added in order to avoid requiring banks and insurance companies to register. However, the amendments at least clarified that no registration was required of such plans themselves. 99 S. Ct. at 799.

41. 99 S. Ct. at 799; S. ReP. No. 184, 9 lst Cong., 2d Sess. 27 (1969).

42. 15 U.S.C. $\$ 77 \mathrm{~d}(2)(1976)$.

43. 17 C.F.R. $\$ 230.146$ (1978). 
employee benefit plans from the registration requirements of the 1933 Act. In those cases where registration is still required, Form S-8 has been adopted to provide a relatively simple registration mechanism. ${ }^{44}$

\section{Fraud.}

Section 17(a) of the 1933 Act, ${ }^{45}$ section 10(b) of the $1934 \mathrm{Act}^{46}$ and Rule $10 \mathrm{~b}-5^{47}$ promulgated under the 1934 Act all prohibit fraud in connection with securities transactions. The application of those sections to the granting of interests in employee benefit plans, to the extent left open by the Court in Daniel, raises a number of complicated issues.

Section 17(a) applies only to the offer or sale (not the purchase) of securities and prohibits the direct or imdirect obtaining of "money or property by means of any untrue statement of a material fact or any omission to state a material fact necessary im order to make the statements made, in the light of the circumstances under which they were made, not misleading." 48 Paragraph (c) of section 17 specifically provides that the exemptions of section 3 (mcluding section 3(a)(2)) do not apply to section $17 .{ }^{49}$ At this date, it is not clear whether a private right of action exists under section $17 .^{50}$ Nor is it clear whether section 17, like section 10 and Rule $10 \mathrm{~b}-5$, requires an element of scienter. ${ }^{51}$ In addition, in no case is it entirely clear what scienter embraces. ${ }^{52}$ Furthermore, while the giving of services could conceivably constitute "consideration" under soine circumstances (for example, in a voluntary plan) in order to bring such transactions within the meaning of the term "sale," it is not at all clear that the services provided by one who is

44. See General lnstructions to Form S-8, 2 Fed. SEC. L. ReP. (CCH) I 7198 (1979).

45. 15 U.S.C. $\& 77 q(a)$ (1976).

46. $I d . \S 78 \mathrm{j}(\mathrm{b})$.

47. 17 C.F.R. \& 240.10b-5 (1978).

48. 15 U.S.C. \& $77 q(a)(1976)$.

49. $I d . \S 77 \mathrm{q}(\mathrm{c})$.

50. See, e.g., International Bhd. of Teamsters v. Daniel, 99 S. Ct. 790, 795 n.9 (1979); Blue Chip Stamps v. Manor Drug Stores, 421 U.S. 723,734 n.6 (1975).

51. See, e.g., Ernst \& Emst v. Hochfelder, 425 U.S. 185 (1976) (scienter required in private damage action premised on Rule 10b-5); SEC v. American Realty Trust, 586 F.2d 1001 (4th Cir. 1978) (scienter not required in SEC action for injunction under § 17(a)); SEC v. Coven, 581 F.2d 1020 (2d Cir. 1978) (scienter not required in SEC action for injunction under $§ 17$ (a)), cert. denied, 99 S. Ct. 1432 (1979); Sanders v. John Nuveen \& Co., 554 F.2d 790 (7th Cir. 1977) (scienter required in private damage action premised on § 17(a)); SEC v. World Radio Mission, Inc., 544 F.2d 535 (1st Cir. 1976) (no scienter required in SEC action under § 17(a)); SEC v. Southwest Coal \& Energy Co., 439 F. Supp. 820 (W.D. La. 1977) (no interest required in SEC action under $\S 17(a)$ ); SEC v. Cenco Inc., 436 F. Supp. 193 (N.D. Ill. 1977) (scienter required in SEC action under $\S 17(\mathrm{a}))$.

52. See, e.g., Rolf v. Blyth, Eastman Dillon \& Co., 570 F.2d 38, $44-48$ (2d Cir.) (reckless disregard may constitute scienter), cert. denied, 439 U.S. 1039 (1978). 
a beneficiary of a pension or profit sharing plan, including an ESOP, are in the nature of "inoney or property" as required by section 17 .

It is soinewhat clearer that section $10(\mathrm{~b})$ and Rule $10 \mathrm{~b}-5$ require scienter ${ }^{53}$ and provide for a private right of action. ${ }^{54}$ Moreover, the language of Rule 10b-5 is somewhat broader than that of section 17, making it unlawful for any person "to make any untrue statement of a material fact or to omit to state a material fact necessary" in connection with the purchase or sale of any security. ${ }^{55}$

The volume of recent decisions ${ }^{56}$ and articles ${ }^{57}$ focusing on the application of the antifraud provisions to employee benefit plans is suffcient to render an in-depth analysis in this Article unnecessary. It is important to realize, however, that even after the Court's decision in Daniel, the questions are not all answered. An approach to their resolution will be considered subsequently. ${ }^{58}$

\section{E. Plan Registration.}

A final aspect of the securities laws that bears directly on einployee benefit plans in general is the registration requirement of the 1934 Act, ${ }^{59}$ requiring, inter alia, that an "issuer" with assets in excess of one million dollars and more than 500 record owners of its equity securities register such securities under section $12(\mathrm{~g})$ of the Act. ${ }^{60}$ In substantially all cases, however, the exeinptions provided by Rule $12 \mathrm{~h}-2(\mathrm{a}){ }^{61}$ Rule $12 \mathrm{~h}-2(\mathrm{~b})^{62}$ and section $12(\mathrm{~g})(2)(\mathrm{H})^{63}$ of the statute are sufficient to avoid any requirement that the plan or trust register the imterests held by ben-

53. Ernst \& Ernst v. Hochfelder, 425 U.S. 185 (1976). While the question has not yet been absolutely resolved, the reasoning of the Court in that case seems logically to compel the conclusion that scienter is required in SEC actions under Rule 10b-5 and section 10(b). However, the lower federal courts remain divided. See note 51 supra.

54. Blue Chip Stamps v. Manor Drug Stores, 421 U.S. 723, 730 (1975).

55. 17 C.F.R. $\S 240.10$ b-5 (1978).

56. See, e.g., Schlansky v. United Merchants \& Mfrs., Inc., 443 F. Supp. 1054 (S.D.N.Y. 1977); Robinson v. United Mine Workers, 435 F. Supp. 245 (D.D.C. 1977); Weins v. International Bhd. of Teamsters, [1977-1978 Transfer Binder] FED. SEC. L. REP. (CCH) I 96,005 (C.D. Cal. 1977); Hurn v. Retirement Fund Trust, 424 F. Supp. 80 (C.D. Cal. 1976).

57. See, e.g., Report, $A$ Report to the Committee on Federal Regulation of Securities From the Study Group of the 1933 Act-General Subcommittee on Daniel, et al. v. International Brotherhood of Teamsters, 32 Bus. LAw. 1925 (1977); Comment, Application of the Federal Securities Laws to Noncontributory, Defined Benefit Pension Plans, 45 U. CHI. L. REV. 124 (1977).

58. See Part IV infra.

59. 15 U.S.C. $\$ 78 l(\mathrm{~g})(1976)$.

60. Id.

61. 17 C.F.R. $\$ 240.12 \mathrm{~h}-2$ (a) (1978) (exempting non-transferable interests in employee benefit plans).

62. Id. $\$ 240.12 \mathrm{~h}-2(\mathrm{~b})$ (exempting interests in common trust funds held by a bank).

63. 15 U.S.C. $\$ 78 / \mathrm{g})(2)(\mathrm{H})(1976)$ (exeinpting interests in trust funds held by a bank for a plan qualified under I.R.C. \$ 401). 
eficiaries.

\section{F. Plans Involving Employer Securities.}

The preceding portions of this section summarized those aspects of the 1933 and 1934 Acts of general applicability-actual or potentialto einployee benefit plans. While the issues are generally significant and sufficiently unclear to have generated the controversy that surrounded the progression of Daniel through the courts, they become far more complex in the case of plans such as ESOPs and stock option plans that involve investınents in employer securities, because such plans clearly involve securities and clearly involve sales. Moreover, such plans trigger the various securities law provisions that govern the relationship between insiders and the market and the relationship between an issuer or its affiliates and the market.

1. Sale and Resale. When an issuer contributes securities to an ESOP in lieu of cash, there clearly seems to be a sale of securities. ${ }^{64}$ The saine is true when an einployee acquires stock through exercise of a stock option or an SAR. Generally, the only exemption available to permit such sales without registration under the 1933 Act is that provided by section 4(2) for transactions "not involving any public offering." Pursuant to Rule 146, discussed above, ${ }^{65}$ the typical ESOP transaction should be viewed as an issuance to the trust, a single purchaser, ratlier than to the various beneficiaries. ${ }^{66}$ In the case of stock option plans, the availability of the section 4(2) option depends upon the nuinber of sales to be inade pursuant to the exercise of options. Furthermore, at least to the extent that Rule 146 reflects the law rather than an administrative interpretation, the availability of the section 4(2) exeinption depends on the. knowledge the purchaser lias of the issuer's affairs as well as the purchaser's sophistication. In the trust con-

64. In this procedure, which is sanctioned by the applicable tax laws, some no-action letters from the staff of the SEC appear to bring the transaction within the "no sale" theory applicable to interests in plans. See, e.g., Hurley Electromics, Inc. (avail. June 21, 1976), [1976-1977 Transfer Binder] FED. SEC. L. REP. (CCH) I 80,637; Apparel Affiliates, Inc. (avail. Aug. 15, 1975); Lakeside Bridge \& Steel Co. (avail. Aug. 15, 1975). See also Holland \& Yerkes, supra note 11, at 1735. However, when securities are contributed in heu of cash, such an approach seems to go far beyond the traditional role of the "no sale" theory.

65. See text accompanying notes 42-44 supra.

66. The issue, however, is not entirely free from doubt. Subsection (g)(2)(ii) of Rule 146, 17 C.F.R. $\$ 230.146(\mathrm{~g})(2)(\mathrm{ii})(1978)$, indicates that the trust would be the single purchaser unless it was "organized for the specific purpose of acquiring the securities." The better-reasoned view, however, would appear to be that the "specific purpose" of the trust is not the acquisition of securities, but the obtaining of various employer and employee benefits associated with an ESOP. As to plans that allocate securities to participants' accounts, provide pass-through voting rights, and give specific rights to securities upon termination of employinent, see Stafford, supra note 40, at 873 . 
text, that question is probably not meaningful; in the option context, it can be significant. ${ }^{67}$ Where no exemption is available, registration is required, although agaim Form S-8 provides a relatively simplified registration procedure. ${ }^{68}$

When a plan itself desires to sell employer securities, the applicable rules embodied in the 1933 Act have been strictly interpreted. If a plan acquires shares from the issuer, pubhic resale is not permitted, except pursuant to Rule $144,{ }^{69}$ since the plan would be an underwriter. Shares acquired in the public market, however, may be resold, and Rule 144 would apply as to volume and manner of sale if the plan and trust are sufficiently close to the issuer to be deemed "affiliates."

When an employee receives employer securities from an ESOP or similar trust, the distribution is legitimately not a "sale" and no securities law consequences should attach. A sale requires a transfer "for value," $" 71$ and liere the employee transfers nothing to the trust im return for the distribution. Where, however, the employee has a choice between cash and stock, it is arguable that the employee is making an investment decision and that an exemption from registration must be found within the provisions of the 1933 Act. $^{72}$

After an employee receives securities, either by exercise of an option or by distribution from a trust, it is reasonable to expect that a subsequent resale will occur. The permissibility of such a sale, absent registration, is open to some doubt. Under any theory, if the process by which the employee receives the securities includes a registration stateinent under the 1933 Act, the employee would come within the section 4(1) exemption ${ }^{73}$ as a person other than an "issuer, underwriter or dealer," and resales should be freely permitted. If the seller is an "affiliate" of the issuer, ${ }^{74}$ however, the issue becomes more difficult. In that context, if the sale constitutes a "distribution," a person acquiring the shares from or selling them for an affiliate is within the statutory defini-

67. See SEC v. Ralston Purina Co., 346 U.S. 119 (1953).

68. See General Instructions to Form S-8, supra note 44.

69. 17 C.F.R. \& 230.144 (1978).

70. See, e.g., J.C. Penney Co. (avail. May 10, 1978), [1978 Transfer Binder] FED. SEc. L. REP. (CCH) I 81,615; MEM Co. (avail. Mar. 14, 1974).

71. See text accompanying note 29 supra.

72. See text accompanying notes 96-101 infra. But see McDonald's Corp. (avail. Feb. 17, 1977); Eastman Kodak Co. (avail. Feb. 23, 1976); Stafford, supra note 40, at 874.

73. 15 U.S.C. $\$ 77 \mathrm{~d}(1)$ (1976). The exemption will be available only if the employer is not an "affiliate" of the issuer. See id. $\S 77 \mathrm{~b}(11)$. The law remains unclear even in this context, however, because under some circumstances such an employee could arguably come within the 1933 Act definition of an underwriter, 15 U.S.C. \& 77b(11) (1976), in which case his resale would require registration. Such arguments have generally not been pressed.

74. See Rule 144(a)(1), 17 C.F.R. § 230.144(a)(1) (1978). 
tion of an underwriter. ${ }^{75}$ Thus, such a transaction must either be registered under the 1933 Act or be made within the limitations imposed by Rule $144 .{ }^{76}$

If the process by which the employee receives securities does not involve registration, the permissibility of resales without registration is even more doubtful. For the optionee, the safe course is to follow the two-year holding period and sales volume limitations of Rule 144. With respect to the ESOP distributee, the SEC staff appears to have adopted the position that whether distributees may sell freely, or must instead sell under Rule 144, depends on the availability of public information about the issuer, the number of shares distributcd relative to the publicly traded sharès and the typical trading volume. ${ }^{77}$ While such distinctions may be sensible from a policy standpoimt, their justification within the confines of the statutory language is tenuous. To the extent that it can be discerned, it appears that if the number of shares being distributed is large in relation to the market, a "distribution" is involved. The subsequent sale, traceable to the issuer (without regard to the time lapse in the tracing), makes the seller an "underwriter" within section 2(11) and denies the possibility of a section 4(1) exemption. Discerning the significance of the availability of public information in this process defies any logical statutory analysis.

2. Insider Trading. The law of insider trading, developing largely out of SEC v. Texas Gulf Sulphur, ${ }^{78}$ is far froin settled. ${ }^{79}$ However, it is generally true that purchases by "insiders" or their "tippees" in possession of material nonpublic information violate Rule $10 \mathrm{~b}-5$. In the stock option context, questions have arisen as to the propriety of grants ${ }^{80}$ and exercises $^{81}$ of options while there is undisclosed public information. In the ESOP context, there appear to be no cases on point, but the fairly close relationship between the issuer and the trust, together with rela-

75. 15 U.S.C. $\$ 77 \mathrm{~b}(11)$ (1976).

76. 17 C.F.R. $\& 230.144$ (1978). Rule 144 provides that persons making sales within its limitations are not engaged in distributions.

77. See Sargent Indus., Inc. (avail. Jan. 30, 1978); Sun Co. (avail. Nov. 3, 1977); Sun Co. (avail. Oct. 10, 1977); San Jose Water Works (avail. Sept. 19, 1977); San Jose Water Works (avail. May 7, 1977), [1977-1978 Transfer Binder] FED. SEC. L. ReP. (CCH) I] 81,196; American Pacesetter (avail. Apr. 28, 1977); Sargent Indus., Inc. (avail. Jan. 7, 1977); Sargent Indus., Inc. (avail. June 24, 1976); Lion Uniform (avail. Feb. 9, 1976); R.V. Weatherford Co. (avail. July 7, 1975); Securities Act Release No. 5750, supra note 10.

78. 401 F.2d 833 (2d Cir. 1968), cert. denied, 404 U.S. 1005 (1971).

79. See generally W. Painter, Federal Regulation of Insider Trading (1968).

80. See, e.g., SEC v. Texas Gulf Sulphur, 401 F.2d 833, 857 n.24 (2d Cir. 1968), cert. denied, 404 U.S. 1005 (1971).

81. See, e.g., Whiting v. Dow Chem. Co., 523 F.2d 680 (2d Cir. 1975). See also Rule 16b-6, 17 C.F.R. § 240.16b-6 (1978). 
tively frequent trust purchases often made in the open market, creates an ever-present risk of violation, particularly simce the concept of "materiality" is inherently vague. ${ }^{82}$

3. Short-Swing Trading Provisions. Scction 16(a) of the 1934 $\mathrm{Act}^{83}$ requires that officers, directors and persons owning more than ten percent of the outstanding shares of an equity security of a corporation tlrat has outstanding a security registered pursuant to the 1934 Act must file reports with the Commission upon any purchase or sale of the corporation's securities. ${ }^{84}$ Section 13 (d) requires a more extensive filing by any person acquiring a five percent holding of a class of such equity securities. ${ }^{85}$ Section 16 (b) provides that any profit received by a person required to report under section 16(a) on a purchase and sale, or sale and purchase, taking place within six inonths of each other is recoverable by the corporation. ${ }^{86}$ In connection with stock option plans and ESOPs, significant questions arise about the precise definition of a "sale"87 (for example, whether there is a "sale" when the issuing corporation inerges into another corporation ${ }^{88}$ ) and whether a person violates section 16(b) when a trust of which he is a beneficiary, or with respect to which he has solne form of administrative relationship, makes a purchase or sale. Although the rules adopted pursuant to sections 13 and 16 have resolved many of the issues, their application is botll confusing and incoinplete. ${ }^{89}$

4. Corporate Purchases. Rule $10 \mathrm{~b}-6^{90}$ is designed primarily to preclude an issuer or underwriter from purchasmg securities in the market, thereby bidding up the inarket price, and then unloading a greater volume of securities at the artificially inflated price. ${ }^{91}$ Consequently, the Rule prohibits purchases by a person who is engaged in a distribution of securities. While that concept may be simply stated, the precise circumstances under which the objectionable behavior can take place are many and varied, and the Rule is correspondingly lengtliy and intricate. As a result, whenever a company-related plan is acquir-

82. See TSC Indus., Inc. v. Northway, Inc., 426 U.S. 438,449 (1976) (defining materiality in a proxy stateinent context as information "that a reasonable shareholder would consider . . . important in deciding how to vote").

83. 15 U.S.C. \& 78p(a) (1976).

84. Id.

85. $I d . \& 78 \mathrm{~m}(\mathrm{~d})$.

86. $I d . \& 78 \mathrm{p}(\mathrm{b})$.

87. See id. \& 78c(a)(14) ("The [term] 'sale' . . . include[s] any contract to sell or otherwise dispose of").

88. See, eg., Kern County Land Co. v. Occidental Petroleum Corp., 411 U.S. 582 (1973).

89. See generally Holland \& Yerkes, supra note 11, at 1749-52.

90. 17 C.F.R. \& 240.10b-6 (1978).

91. $I d$. 
ing employer securities, there is a substantial risk that plan purchases contemporaneous with issuer sales will give rise to a Rule 10b-6 violation. That difficulty is exacerbated by the long held view that any corporation with a convertible security outstanding is engaged in a constant sale or distribution of the security into which the senior security is convertible. ${ }^{22}$ If, then, an employee benefit plan acquires the cominon stock, its necessarily close relationship with the issuer creates difficulties. While the staff of the SEC has been helpful in seeking to alleviate that problen by issuing exemption orders pursuant to Rule 10b-6(f) under such circumstances, provided certain procedures designed to protect the marketplace are followed, ${ }^{93}$ there is a burden involved in obtaining an exemption, and there are inevitably some inadvertent violations of Rule 10b- 6 .

\section{Securities Law Interests Affected by Employee Benefit Plans}

The foregoing sections of this Article have in large measure been preliminary in nature. They have sought to provide some insight imto the pertinent provisions and complexity of the securities laws as applied to employee benefit plans, but have not sought to present any clear analysis of how the various potential problems for different sorts of plans can or should be solved under existing law. The reasons for that are two-fold. First, and primarily, that function has been adequately performed elsewhere. ${ }^{94}$ But second, and particularly in a symposiun of this nature, there is some question as to whether the role served in society by the securities laws is of such a nature that they should be applied automatically, and without reconsideration, to the various types of employee benefit plans that have been developed over the past several years. ${ }^{95}$ It is useful, therefore, to take a step backward

92. See, e.g., SEC v. Georgia-Pacific Corp., [1964-1966 Transfer Binder] FED. SEC. L. REP. (CCH) $\Uparrow 91,692$ (S.D.N.Y. 1966). For example, if a corporation has outstanding a preferred stock that is convertible into its common stock, the corporation is deemed to be in a constant distribution of the common stock.

93. See, e.g., Centennial Corp. (avail. Aug. 29, 1977), [1977-1978 Transfer Binder] FED. SEC. L. REP. (CCH) \ 81,320; Modern Merchandising, Inc. (avail. June 5, 1977); Inter-Regional Financial Group, Inc. (avail. Mar. 11, 1977), [1976-1977 Transfer Binder] Fed. SEC. L. REP. (CCH) If 81,042; Phillips Indus., Inc. (avail. Jan. 27, 1977); Tandy Corp. (avail. Dec. 19, 1976), [1976-1977 Transfer Binder] FED. SEc. L. REP. (CCH) If 80,850; Computer Autonation, Inc. (avail. Oct. 15, 1975). See also Securities Exchange Act Release No. 10,539 (Dec. 6, 1973), [1973 Transfer Binder] FED. SEC. L. REP. (CCH) $\ 79,600$.

94. See, e.g., Stafford, supra note 40; authorities cited at note 11 supra.

95. Indeed, the various ways in which the SEC has sought actively to reduce the interference with employee plans resulting from the securities laws, even resorting to the "no sale" fiction, suggest this conclusion. 
and to look at the fundamental purposes for which the securities laws were adopted rather than merely looking at the precise language of each existing provision of those laws.

Insofar as the securities laws regulate the issuance and sale of securities, rather than the regulation of members of the securities industry or of relationships between issuers and their shareholders, two primary interests can be seen. The first is the protection of potential purchasers of securities. The second is the protection of the securities markets. The latter concern, recognized as important in the wake of the 1929 collapse, involves building confidence in the fairness of securities markets and eliminating those aspects of securities trading that tend to erode confidence.

\section{A. Purchaser Interests.}

Most of the 1933 Act is directed at protecting purchaser interests. Its theory follows Justice Brandeis' oft-quoted phrase concerning sunlight, disinfectant, electric light and policeinen. ${ }^{96}$ Unlike inost state legislatures, which have opted for a paternalistic form of protective regulation, ${ }^{97}$ the Congress, at least in 1933, preferred a measure of investor freedom: the Act allows investors to make foolish decisions provided they are given full and accurate information with which to make those decisions. Thus, the 1933 Act requires a registration statenent and prospectus containing information about specified topics. The liabilities are very strict for misstatements or omissions.

Given the tenor of the 1933 Act, it might appear at first blush that there is a proper role for the application of such laws to the granting of interests in einployee benefit plans. The anticipation of pension benefits has become a sufficiently important aspect of total compensation that an einployee given different employment opportunities will indeed consider a comparison of their retirement programs. At the key executive level, stock option plans and the like can also be a significant determinant in an individual's decision regarding employment. An employee's interest in a pension plan is certainly related to an investment decision, despite what the Supreme Court nay have said in Daniel. ${ }^{98}$ Given the importance of the typical employee's retirement anticipations, and the amount of labor that the einployee will offer to the employer in order to

96. "Publicity is justly commended as a remedy for social and industrial diseases. Sunlight is said to be the best of disinfectants; electric light the most efficient policeman." L. BRANDEIS, Other People's Money and how the Bankers Use It 62 (1914).

97. See J. Mofsky, Blue Sky Restrictions on New Business Promotions 15 (1971).

98. "[T]he type of pension plan at issue in this case bears no resemblance to the kind of financial interests the Securities Acts were designed to regulate." $99 \mathrm{~S}$. Ct. at 800 . 
achieve such benefits, it is probable that the employee's "investment" in a retirement plan is among the most significant investinents he or she will inake in a lifetime. Certainly one can argue that if Corporation $A$ offers a defined benefit plan with $\$ 500$ per month pension while Corporation $B$ offers a similar plan with $\$ 400$ per month pension, it may be pertinent to a potential employee that Corporation $A$ is on the verge of bankruptcy while Corporation $B$ is not.

With respect to the antifraud provisions the argument is even stronger. Even if an affirmative disclosure document in the nature of a prospectus is not required, employers should not be entitled to make an untrue statement of a naterial fact or to state a half-truth. However, as the Court noted in Daniel, ${ }^{99}$ that arguinent may assume too much. For although the securities laws have been properly extended to reach unusual as well as typical investments, there remams an ainbiguous distimction between truly investment-oriented decisions and decisions primarily related to other purposes. The purchase of a residence, for example, can certainly be characterized as an "investment." However, one would not reasonably expect all real estate developers to provide hoine purchasers with a full description of the developer's business in order to enable the purchaser to evaluate the corporation's ability to respond in damages if the house turns out to have been poorly built. The purchase of an autoinobile can be characterized as an investment without any difficulty, and yet one would not rationally suggest the general application of the securities laws to automobile dealers. In short, any transaction in which one party parts with solne form of consideration, monetary or otherwise, in exchange for something that is not consuined in the reasonably immediate future can be characterized as an "investinent" without offending relevant court decisions.

While it may be true that a large number of transactions in which an individual participates during his or her lifetime can be characterized as investments, it is not at all clear that all of those transactions should be subject to the securities laws. One cannot rationally argue for the right to commit fraud; however, the 1933 and 1934 Acts and the rules proinulgated thereunder do not stand naked. They were adopted with reference to traditional investment decisions and they stand against a background of forty-five years of judicial and administrative determination. What is considered "fraud" for purposes of Rule 10b$5^{100}$ in an industry of peculiar and unique importance to the national econoiny inay well be beyond the commonly accepted view of fraud.

99. Id, at 797.

100. See text accompanying note 55 supra. 
Indeed, were that not true, securities law concepts of fraud could be eliminated and reliance liappily placed upon traditional common law notions.

Thus, to argue that the antifraud provisions of the securities laws slould not apply to typical employee benefit plans is not to argue for the permissibility of fraud, but merely to assert that the highly specialized meaning of the term "fraud" that has developed in the securities law field should not apply to transactions that the securities laws were not written to cover. To soine extent, the adoption of ERISA recognizes this premise. ${ }^{101}$ While the SEC inay be correct in asserting that ERISA did not preempt the securities laws, it seems clear that Congress perceived that a vacuum existed, and Congress drafted and passed ERISA to fill that vacuuin. If the securities laws apply generally to employee benefit plans of any type, the vacuum, which Congress sought to fill, was not a real vacuum at all.

The saine difficulty that the Supreme Court faced in the line of cases beginning with SEC v. C.M. Joiner Leasing Corp. ${ }^{102}$ and extending through Daniel remains: namely, determining the real meaning of an "investment contract." It is not enough to talk about the efforts of others, because increases in housing prices or in the value of automobiles or works of art are primarily through the efforts of others and not through the efforts of the owner. Perhaps, as the Court suggested in United Housing Foundation, Inc. v. Forman, ${ }^{103}$ the inquiry should not be whether the contract can properly be characterized as an investinent contract, but rather whether the decisional process can be characterized as the sort of process to which the securities laws were addressed. ${ }^{104}$ To pose that question is not, of course, to answer it, and unfortunately, there is no clearer solution than the one the Court has been able to generate. It can at least be suggested, however, that the extension of Daniel beyond the relatively limited scope suggested by the Court ${ }^{105}$-its application only to non-contributory, compulsory pension plans-is not unreasonable. ${ }^{106}$

Fundainentally, employment decisions are not investment decisions. The einployee who accepts a job on an assenbly line may be acquiring an interest in a pension plan, but he is not making an invest-

101. See International Bhd. of Teamsters v. Daniel, 99 S. Ct. 790, 801-02 (1979).

102. 320 U.S. 344 (1943).

103. 421 U.S. 837 (1975).

104. Id. at 858.

105. $99 \mathrm{~S}$. Ct. at 802.

106. At least one federal district court has already extended Daniel to contributory plans. Tanuggi v. Grolier, Inc., [1978-1979 Transfer Binder] FED. SEC. L. REP. (CCH) If 96,880 (S.D.N.Y. May 14, 1979). 
Inent in the pension plan assets in the sense to which the securities laws were addressed. Of the various types of employee benefit plans outlined earlier in this Article, ${ }^{107}$ the only ones that truly mvolve typical investment decisions, as the Court implied in Daniel, ${ }^{108}$ are voluntary, contributory plans that give an employee the choice of receiving cash or stock in distribution from a trust and those involving the exercise of a stock option. ${ }^{109}$ The last of these, usually exercised when there is a substantial discrepaney between exercise price and market price, becomes a significant investment decision only because of mcentives to retain the stock for a significant period of time after exercise.

\section{B. Market Interests.}

To the extent that provisions of the securities laws address market interests rather than purchaser interests, conclusions must be quite different. Regardless of whether an employee is making an investment decision, if the structure of the employee benefit plan has actual or potential significant impact upon securities markets, there is a clear basis for the application of the securities laws. ${ }^{110}$ With regard to the large majority of pension plans that do not involve investment in employer securities hittle need be said herc. While substantial securities law questions pertain to the trading practices of such plans, they are little different in nature from questions generally pertincnt to the activities of pooled investment funds. With respect to plans that do involve employer securities, primarily ESOPs, stock option plans and the like, the unique ways in which there will be a general inarkct impact justify application of the securities laws.

To assert, however, that there is a legitimate role for the securities laws is not to concede that the securities law provisions that now serve market-oriented interests should be inflexibly applied to employee ben-

107. See Part I supra.

108. $99 \mathrm{~S}$. Ct. at 801.

109. To some extent, although with slightly more limited focus and some potential continued confusion, such an approach was proposed in S. 3017, imtroduced May 1, 1978. S. 3017, 95th Cong., 2d Sess. (1978), reprinted in Joint Hearings on S. 3017 Before the Subcomm. on Labor of the Senate Comm. on Human Resources and the Subcomm. on Private Pension Plans and Employee Fringe Benefits of the Senate Comm. on Finance, 95th Cong., 2d Sess. 3 (1978). Section 274 would amend $\S 514$ of ERISA to provide an expansion of the ERISA preemption provisions that would preclude viewing interests in employee benefit plans, other than voluntary eligible individual account plans, as securities under the 1933 Act, the 1934 Act or state securities laws.

110. Certain provisions of the securities laws are designed to protect not the immediate investor but the integrity of the market itself. See, e.g., 15 U.S.C. $\$ 78$ j (1976) and Rule 10b-5, 17 C.F.R. \& 240.10b-5 (1978) (prevention of market manipulation); 15 U.S.C. \& 78p (1976) (shortswing trading by substantial shareholders). These provisions should be apphed as fully to employee benefit plans as to other investors in the market. 
efit plans involving significant investinents in employer securities. The application of the securities laws to such plans is labyrinthian and creates substantial burdens for corporate lawyers and SEC staff, not to inention substantial legal expenses for employers. In large measure, this situation is the result of the existing statutes and not of any overzealous behavior at the Commission. Rationalizing that irrational system, which will likely require statutory amendment, should benefit all concerned.

\section{A Rational Approach to the Application of the Securities laws to Employee Benefit Plans}

As noted above, the registration and antifraud provisions of the securities laws should be apphicable to employee benefit plans only in very limited circumstances. ${ }^{111}$ Section 3(a)(2) of the 1933 Act provides a general exemption from the registration provisions of that act for most such plans, but its application is at best unclear.

Interpretations of section 3(a)(2) range from the view of the International Brotherhood of Teamsters (which was supported by the Court ${ }^{112}$ ) - that it covers only the interests in funds sold by banks and insurance companies to pension plans ${ }^{13}$ - to the view that it embraces not only the employee's imterest in a plan but also the distribution of einployer securities to the employee. ${ }^{114}$ Furthermore, the section makes unsatisfactory and unreasonable distinctions. For example, it may be appropriate to establish some minimum degree of independence between the employer and the keeper of the plan assets. But it is not useful-as section 3(a)(2) does-to generate questions about single rather than collective trust funds or to create technical barriers to the availability of the exemption. The alternative exemption-the "no sale" fiction-may once have been useful, but has now been exposed and cannot withstand scrutimy. ${ }^{115} \mathrm{~A}$ thorough revision of section 3(a)(2) and a concomitant reexamination of the antifraud provisions would be useful in order to clarify when required disclosure under the securities laws can serve a meaningful function and when the extraordinary securities law notion of fraud should be applied. The author's views on those questions have been expressed above. ${ }^{116}$

The proper role of the market-oriented concerns of the securities

111. See text accompanying notes $34-58$ supra.

112. 99 S. Ct. at 799.

113. See SEC Daniel Brief, supra note 15 , at $60-61$.

114. See Washing, Resales Under Qualified Plans, 9 Rev. SEC. REg. 955 (1976).

115. See note 32 supra and accompanying text.

116. See text accompanying notes $36-41,45-58$ supra. 
laws that relate to plans that invest in enployer securities cannot be determined so easily. Those provisions are found primarily in the resale provisions of Rule $144,{ }^{117}$ the insider trading proscription of Rule 10b5,118 the short-swing sale provisions of section $16^{119}$ and the purchase restrictions of Rule $10 \mathrm{~b}-6.120$

\section{A. The Sale of Employer Securities.}

The staff of the Commission has, with explicit Commission approval, adopted the general position that when einployer securities are distributed to employees from an employee benefit trust they may thereafter be sold by the participants without compliance witl the registration provisions of the 1933 Act so long as two conditions are met. First, there must be generally available public information regarding the issuer. Second, the number of shares in the plan and of any participant's interest therein must be relatively sinall in relation to the number of shares in the market. ${ }^{121}$ While this is certainly not the first time the SEC has imposed extra-legal conditions on its willingness to agree with a legitimate request through the no-action procedure, that does not make it any nore appropriate. ${ }^{122}$ Particularly at a time when legislative proposals are under consideration to clarify the relationship between employee plans and the securities laws, ${ }^{123}$ it would seein appropriate to examine the pertinent considerations and to propose statutory amendments responsive to those considerations.

These transactions primarily involve plans in the nature of ESOPs. The difficulty with ESOPs is that they liave been adopted by large corporations with seeurities listed on national securities exchanges as well as by small, privately-lield "family" corporations. There is no policy basis for precluding einployees who receive shares of corporations of the former type from disposing of those shares, since by the nature of sucl corporations-and the laws already applicable to them-there is available to potential purchasers a substantial quantity of information about the issuer. There is no reason for employee sales to trigger a requirement that information already available to the public be assembled in a new disclosure document. There is, however, reasonable basis for concern with respect to the small, privately-lield family corpora-

117. 17 C.F.R. § 230.144 (1978).

118. Id. $\$ 240.10 \mathrm{~b}-5$.

119. 15 U.S.C. $\S 78 \mathrm{p}$ (a) (1976).

120. 17 C.F.R. $\$ 240.10 b-6$ (1978).

121. See Securities Act Release No. 5750, supra note 10.

122. See text accompanying note 133 infra.

123. See S. 3017, supra note 109. Also see S. 209, introduced Jan. 24, 1979, after the Daniel decision. S. 209, 96th Cong., Ist Sess., 125 Cong. REC. S560 (daily ed. Jan. 24, 1979). 
tions. There is little available information about such corporations, and trading in their sliares simply should not commence absent the public disclosure of information. Similarly, concern for the stability of markets suggests the reasonableness of concern with the volume of securities that might suddenly be placed on the market.

It is not clear, however, that the policy view espoused by the SEC in its no-action letters is required. Trading without adequate public information is a far inore general concern than trading shares received froin employee plans. Some years ago, in response to such general concerns, the SEC adopted Rule 15c2-11 under the 1934 Act. ${ }^{124}$ When Rule 144 was adopted it specifically embraced the concept of Rule $15 \mathrm{c} 2-11$, requiring that the Rule $15 \mathrm{c} 2-11$ information be available at least prior to sales pursuant to Rule $144 .{ }^{125}$ Rule $15 \mathrm{c} 2-11$ provides that brokers cannot commence making a market in a security unless there is publicly available the information specified in that rule, which would appear to be entitled to a presumption that it is sufficient to ensure fair trading markets. If Rule 15c2-11 solves the problem to which it was directed, there need be little concern with the disposition of shares received on distribution from employee plans. Certainly there could be isolated trades but no trading market could suddenly develop. It is not sensible to allow isolated trades to sliape significant policy decisions. If, on the other liand, Rule $15 \mathrm{c} 2-11$ is not viewed as providing adequate protection, then that is the rule to which attention sliould be directed.

With respect to volume concerns, resolution of the problem is inore difficult. Other than in the context of determining when a "distribution" is taking place, for the purpose of deciding whether a person is a statutory underwriter, no provision of the securities laws gives the SEC jurisdiction over such questions. The volume levels discussed in the ESOP no-action letters do not consider that issue. Yet it is certainly true that significant increases in the number of shares brought to the narket for sale can create a substantial sliort-term disequilibrium. While the recent amendment to the volume limitations of Rule $144^{126}$ might suggest a lessened concern with this issue, it remains of significant interest. Given the statutory limitations, the SEC's only solution inay be to trust the sellers' self-interest in not unnecessarily depressing the inarket, in order to focus on the regulation of brokers (as it did in Rule $15 \mathrm{c} 2-11$ ) or to seek statutory authority to cope with the concerns it senses. Obtaining such a statutory amendinent should require a signifi-

124. 17 C.F.R. $\$ 240.15 c 2-11$ (1971).

125. Rule 144(c)(2), 17 C.F.R. \$ 230.144(c)(2) (1978).

126. Securities Act Release No. 5979 (Sept. 18, 1978), [1978 Transfer Binder] FED. SEc. L. REP. (CCH) I 81,731. 
cant showing of need.

\section{B. Section $16(b)$.}

The difficulties posed by section $16(b)$ with respect to plans investing in einployer securities are complex and border on the irrational. For example, if an officer or a director of a corporation is also on the administrative committee of a benefit plan that purchases employer securities as its only raison d'etre, it is not clear whether the officer or director has "purchased" so that any personal sale by that individual within six inonths before or after the plan purchase is subject to the section 16(b) limitations. If the individual is not a trustee but is a member of the board administration committee that administers the ESOP, it is not clear whether such transactions are purchases by the individual. While the rules proinulgated pursuant to section 16 answer some of these questions, ${ }^{127}$ and various other questions are discussed in a number of no-action letters, ${ }^{128}$ the law and procedures are far from comprehensive. It is not clear, at least with respect to no-action letters, that the SEC's determinations are binding upon private plaimtiffs who bring a section $16(\mathrm{~b})$ action on behalf of the corporation. ${ }^{129}$

It is useful again to look at the broad purposes of section 16(b) rather than trying to focus on specific materials existing under present law. Section 16(b) of the 1934 Act was adopted by Congress as much to increase general faith in the fairness of the securities inarkets as to eliminate the evil of "insider" trading. ${ }^{130}$ If the latter concern were the basis for section 16(b), the test would appropriately be something other than a short-swing test since the evils of insider trading can and do exist with any purchase or sale whether or not it is matched by an offsetting transaction within six months. Furthermore, it is probably true that with few exceptions the typical violator of the section is not the executive who intentionally abuses his inside position but rather the execu-

127. See, e.g., Rule 16a-8, 17 C.F.R. \& 240.16a-8 (1978); Rule 16a-10, id. § 240.16a-10; Rule $16 \mathrm{~b}-3, i d . \$ 240.16 \mathrm{~b}-3$.

128. See, eg., American Pacesetter (avail. Apr. 28, 1977); Montana-Dakota Utils. Co. (avail. Mar. 17, 1977); Texas Gas Transmission Corp. (avail. Oct. 8, 1976); First Wisconsin Bankshares Corp. (avail. Dec. 16, 1970), [1970-1971 Transfer Binder] FED. SEC. L. REP. (CCH) I 77,997. See also Miller, Employee Compensation Plans-Federal Securities Laws Developments, 2 NINTH ANN. INST. ON SEC. REG. 1025, 1053-60 (1977).

129. See, e.g., Lowe's Companies (avail. Mar. 15, 1978) (advising that no action would be taken if officers did not file reports in rehance upon Rule 16a-8(d)(3), 17 C.F.R. \& 240.16a-8(d)(3) (1978), but noting that the application of that rule to the issue in question "is not entirely free from doubt" and then indicating that the availablity of Rule 16a-10 (which exempts from $\S 16(\mathrm{~b})$ hability any transactions exeinpt from the $\$ 16$ (a) reporting obligations) was similarly in doubt).

130. See H.R. ReP. No. 1383, 73d Cong., 2d Sess. (1934), reprinted in I1A, Pt. 2C Bus. ORGANIZATIONS-SEC. REg. 5-15 (1971). 
tive or other person who inadvertently violates the section with no improper intent. This is no doubt true to an even greater extent in the case of the officer or director who has some relation to an employee benefit plan that could cause him or her to be deemed to have acquired interests in shares held by the plan.

Consequently, it is appropriate to clarify under section 16(b) that a purchase inade by an employee benefit plan is not to be considered a purchase by any individual participant, any member of the board of directors or any member of a committee of the board charged with administration of the plan. Such transactions simply do not raise the difficulties to which section $16(\mathrm{~b})$ is directed.

Furthermore, it is appropriate to exempt purchases pursuant to stock options from section 16(b) liability when the option was granted more than six months prior to exercise. ${ }^{131}$ Certainly, it is possible to envision inappropriate transactions involving the exercise of a stock option and the immediate sale by an insider who is aware of adverse inside information and knows that the inarket price is likely to decline substantially. However, the wrong in that situation is unrelated to the exercise of the stock option-which may well have been granted years before-and is precisely the kind of abuse to which Rule $10 \mathrm{~b}-5$ is directed. There is no reason to inake the burden on that officer any lighter or any heavier than the burden on an officer who had exercised his stock option more than six inonths before selling on the basis of such inside information. While such concerns slould perhaps not be sufficient to remove stock option exercises from the reach of section 16, they become inore important in conjunction with the confusion that arises as a result of the unclear state of the law.

\section{Insider Trading.}

To suggest the large-scale reinoval of employee plans from the short-swing liability provisions of section 16(b) of the 1934 Act is not to suggest that abuses cannot occur. The insider trading restrictions that liave arisen as a result of actions under Rule 10b-5, primarily SEC enforcement actions, are important safeguards to the appearance of fair securities markets. However, given the difficulties faced by corporate insiders in determining inateriality, and the inevitably close relationship between corporations and their employee plans, it would be useful for the SEC to sanction, through a release, soine procedure by which an employee plan that regularly purchases or sells employer securities

131. Present Rule 16b-6, 17 C.F.R. $\$ 240.16 b-6$ (1978), does limit, but does not eliminate, liability in such instances. 
might reasonably safeguard itself in making such transactions. ${ }^{132}$

\section{Rule 10b-6.}

The law surrounding Rule $10 \mathrm{~b}-6$ is anong the inost coinplicated to be found in the entire securities area. The current practice of the SEC with respect to einployee plans that acquire employer securities and that have potential Rule 10b-6 difficulties is to grant an exemption from the rule if the issuer or the plan agrees to inake all such purchases according to specified procedures taken from former proposed Rule 13e-2. ${ }^{133}$ This practice suffers from two flaws. First, there is again the use of leverage to accomplish pohicy goals that are quite distinct from the purposes served by the rule. Second, and of greater significance, these procedures will be apphed to employee plans discriminatorily, since their apphication depends solely upon whether Rule 10b-6 would otherwise apply. If there is no reason for the application of Rule 10b-6, then there is no basis for forcing the plan to follow such restrictions in its purchases. If such procedures are important, then under section 13(e) they should be adopted with respect to all employee plans that purchase employer securities. If they are not important, they slould not be applied at all. To require some corporations to follow these procedures because they have an outstanding convertible security and to permit them to avoid the procedures if they redeem the convertible security seems absurd.

\section{CONCLUSION}

The Daniel case has generated substantial discussion regarding the need for and the propriety of amending ERISA so as to clarify the relationship between employee benefit plans and the securities laws. While pending legislation moves in that direction, ${ }^{134}$ it is useful to consider on a broader scale the overall relationship between the securities laws and employee benefit plans and to decide which agencies should be responsible for the administration and regulation of employee benefit plans. All indications are that the proper role of the Securities and Exchange Commission should not be directed toward the employeremployee (or union-employee) relationship, but rather should be lim-

132. See, e.g., Rule 16b-3(e)(3), 17 C.F.R. $\$ 240.16 b-3(e)(3)$ (1978) (establishing, under some circumstances, a "window" period for SAR plans during which such rights must be exercised if the employee is to receive cash).

133. Securities Exchange Act Release No. 8930 (July 13, 1970), [1969-1970 Transfer Binder] FED. SEC. L, REP. (CCH) I 77,837, revised in Securities Exchange Act Release No. 10,539, supra note 93.

134. See notes 109,123 supra. 
ited to those aspects of employer-employee benefit plans that do in fact have an impact on the securities markets generally. In those areas, several existing rules could be improved without adversely affecting the inarkets. To nove in that direction would be a great ineasure of progress. 


\section{.}

